\title{
New Moroccan Migrants in Belgium
}

\section{Hassan Bousetta}

To cite this article: Hassan Bousetta (2008) New Moroccan Migrants in Belgium, Journal of Immigrant \& Refugee Studies, 6:3, 397-408, DOI: 10.1080/15362940802371739

To link to this article: http://dx.doi.org/10.1080/15362940802371739

\section{曲 Published online: 12 Dec 2008.}

\section{Submit your article to this journal 주}

Lll Article views: 124

Q View related articles $\asymp$ 


\title{
New Moroccan Migrants in Belgium
}

\author{
Hassan Bousetta
}

\begin{abstract}
Moroccans in Belgium come close to being the largest immigrant community in the country. It is characterised by being both in a post-migration and migration situation. The Moroccan community in Belgium lies at the juncture of the social experience of an older and newer community of migrants. While there has been extensive research on the legally established, the trajectories of new Moroccan migrants have not been dealt with specifically in the literature. Dwelling on both existing research and on our own fieldwork material, this paper seeks to better study Moroccan undocumented migrants. A tentative etnography is articulated that seeks to better understand the expectations, anticipations and strategic reactions of this group of migrants in relation to immigration policy-making.
\end{abstract}

KEYWORDS. Migration, undocumented, Moroccans, immigration policy, Belgium

\section{INTRODUCTION}

Belgium belongs to a cluster of North West European countries that has a relatively long tradition of immigration. It has undergone several phases of very active immigration both before and after the Second World War. Successive waves of migrants included groups originating from countries

Hassan Bousetta, PhD, is affiliated with National Fund for Scientific Research, Centre for Ethnic and Migration Studies (CEDEM), University of Liège, Liège, Belgium.

Address correspondence to: Hassan Bousetta, $\mathrm{PhD}$, National Fund for Scientific Research, Centre for Ethnic and Migration Studies (CEDEM), University of Liège Bâtiment 31- Boîte 45, Bureau R36, 7, Boulevard du Rectorat, B - 4000 Liège, Belgium (E-mail: Hassan.bousetta@ulg.ac.be).

Journal of Immigrant \& Refugee Studies, Vol. 6(3), 2008

Available online at www.haworthpress.com

(c) 2008 by The Haworth Press. All rights reserved.

doi: 10.1080/15362940802371739 
as diverse as Poland, Italy, Greece, Morocco and Turkey to name but a few. There is a general recognition that immigration has transformed Belgium into a fully-fledge multicultural society. What has also been noted is that while the country was diversifying culturally as a result of previous migration cycles, immigration continued, leading the country into a simultaneous migration and post-migration phase. This was most evident in the early 1990s. While Belgium had to address the emerging tensions and public claims for recognition articulated by the second generation, it was also observing the biggest increase in numbers of new migrants and refugees.

Moroccan immigrants in Belgium have been central to the migration debate since the mid-1960s. Initially attracted as guest workers, Moroccans have settled for good and developed one of the largest immigrant ethnic minority communities. With 81,000 people on the official records, ${ }^{1}$ Moroccans are ranked fourth amongst non-nationals, after Italians, French and Dutch. However, when ethnicity is taken into consideration rather than nationality, the estimated size of this community is more than triple this number. The official figures published by the National Institute for Statistics need to be seen in context - Moroccans have one of the highest rates of naturalisation amongst all categories of foreigners. Taking this fact into account, it is estimated that the Moroccan community represents a group of over 250,000 persons, ranking top with Italians.

The size of the Moroccan community in Belgium was not the main argument for studying them in the context of this project. Features of the Moroccan community in Belgium also include a high concentration in urban areas, as well as the maintenance of an active immigration circuit through family reunion and family formation. Insofar as this community is composed of both an old immigrant guest-worker's component and a new migrant one, the group offers a good strategic-case study for analysing the interaction between migrants' plans and strategies, on the one hand, and state policies, on the other.

This paper focuses on two main sources. The first is a pilot study conducted in Belgium following a similar methodology than that applied in twelve other countries of immigration. For the Belgian case-study, seven interviews have been conducted with four Moroccan migrants and three Belgian policy-makers (local, regional and federal) using a similar interview grid. The second source is a body of knowledge of the Moroccan presence in Belgium accumulated through a number of research projects led by the authors (amongst others: Bousetta, 2001; Bousetta \& Martiniello, 2003; Bousetta, Gsir \& Martiniello, 2006). It is our contention that the tentative and exploratory character of this collective attempt at 
better understanding the expectations, anticipations and strategic reactions of migrants in relation to immigration policy is counterbalanced in the Belgian case by a systematic cross-examination of our research findings. In order to increase the validity and reliability of our interview material, our analysis throughout the paper has sought maximal triangulation of various documentary sources (including a re-examination of interview material collected for earlier research projects), primary and secondary literature.

\section{The Formation of the Moroccan Community in Belgium}

Moroccan immigration in Belgium set off in February 1964 with the signing of a bilateral labour force agreement. This is at least how things are usually presented in the media and commonsense discourse. In reality, Moroccan migration to Belgium existed much earlier, notably between the two World Wars and largely outside the control of both governments. This was an indirect consequence of the French colonial domination of Morocco.

Up until the sixties, Belgium was relatively unknown in Morocco. It is only with the mass industrial immigration of that decade that Belgium became a destination for prospective Moroccan migrants. In this sense, the signing of the bilateral labour force agreement of 1964 was a significant event in terms of migration movements. Not only were large contingents of Moroccan workers to be officially recruited in Belgian industries, but many more Moroccan workers immigrated to Belgium by their own means unofficially, and regularised their situation on the spot. The laissez-faire which characterised the Belgian migration policy of the Sixties encouraged the process of spontaneous immigration of Moroccans outside the official channel established by the bilateral agreement.

Moroccan immigration in Belgium may be divided into four periods: from 1912 till 1964; from 1964 till 1974, from 1974 till 1989 and from 1989, to date. From 1912 till 1964, Moroccans came mainly through French colonial linkages and this migration flow was characterised by its non-permanent character. Moroccans came and went essentially due to their economic and administrative vulnerability between 1918 and 1939 . The signing of the bilateral labour force agreement opened up the most significant period - that of mass industrial immigration. From 461 people censused in 1961, Moroccans multiplied their presence tenfold in the course of a decade: 40,000 Moroccans were registered by the National Institute for Statistics in 1971. From 1974 onwards, with the halt to official recruitment, the period is characterised by the diversification of the sociological profile of Moroccans. Whereas they were mainly young men 
TABLE 1. The Moroccan Population in Belgium (Official Nationality, 1962-2003) $)^{2}$

\begin{tabular}{lrrrrr}
\hline 1962 & 461 & 1988 & 132,589 & 1996 & 140,303 \\
1971 & 39,294 & 1989 & 135,464 & 1997 & 138,252 \\
1981 & 105,133 & 1990 & 138,417 & 1998 & 132,831 \\
1982 & 110,200 & 1991 & 141,660 & 1999 & 125,082 \\
1983 & 115,082 & 1992 & 145,600 & 2000 & 121,984 \\
1984 & 199,083 & 1993 & 144,993 & 2001 & 106,822 \\
1985 & 123,188 & 1994 & 145,363 & 2002 & 90,642 \\
1986 & 123,617 & 1995 & 143,969 & 2003 & 83,631 \\
1987 & 126,095 & & & & \\
\hline
\end{tabular}

Source: Ministry of Interior/ National Institute for the Statistics 2006.

in the previous period, the late Seventies bear witness to a phenomenon of rejuvenation and feminisation. This is the period of family formation and family reunion. Available data indicate that family formation has been quantitatively very significant throughout the period (Table 1). The post1989 phase is characterised by the increasing visibility of Moroccans in the public arena. It is during this period that Moroccans were recorded at their highest, with 145,000 people registered in 1992. This figure decrease from then on, year after year, due to a high naturalisation rate. In 2006, Moroccans represented a population group of 81,000 but are estimated to form an ethnic group of more than 250,000 people.

It is of paramount importance to analyse the pattern of past Moroccan migration in order to get a better view of its current situation. The characteristics of past migration continue to heavily influence the trajectory of this community. The first characteristic is its low-skilled and workingclass dimension. The number of self-employed has long been marginal and the private business created was often not very sophisticated. With the emergence of the second generation, the socio-professional profile of Moroccans has diversified. The situation now is characterised by a form of dualism. A small segment of the second generation made a professional breakthrough in the private sector and performs at quite high professional levels, while a large proportion of the youth remain affected by heavy disadvantages, such as in terms of school performance. As a consequence, their economic participation in Belgian society remains weak.

It should also be mentioned that contrary to other established immigrant communities of European origin established in Belgium, Moroccans are simultaneously living in a post-migration and migration state. Over recent years, Moroccans have received the highest number of long term visas 
for Belgium. In 2006, more than 4,600 Moroccans obtained the right to settle in Belgium, $85 \%$ of those for family reasons. Besides undocumented migration, there is therefore a significant legal Moroccan immigrant flow towards the country. Here, we seek to concentrate on these recent Moroccan migrants. Available data do not always permit a distinction between the fortunes of these new migrants and the older segment of the community. There are, nevertheless, three categories of new Moroccan migrants that have emerged with recent migration: undocumented migrants, family dependents and former students. We mainly concentrate on the first category.

\section{Trajectories of New Moroccan Migrants in the Context of a Restrictive Immigration Policy}

The immigration strategies of Moroccans are influenced in complex ways by Belgian immigration policy. In comparison to the pre-1974 period, the development of Belgium's immigration policy has been characterised by increasing control over access to both its territory and labour market. This was part of a broader process of Europeanization of migration policy. The channels which are nowadays opened for long-term regular immigration are those in place for, firstly, European citizens as part of the freedom of movement framework, secondly, family reunification, thirdly, the admission of foreign students and, finally, a work permit for certain categories of jobs. In practice, only the three latter channels are relevant for new Moroccan migrants. In addition to these routes, Moroccans have also made significant use of visas for short-term visits (less than 3 months) to devise long-term migration strategies. Overstaying a short-term visa is not uncommon for many new Moroccan migrants, a reality which explains why they are also well represented among the undocumented population in Belgium. ${ }^{3}$ Although Belgium was considered by migration experts to be relatively immune from undocumented Moroccan immigrants coming through illegal migration routes, this has changed in recent years. An increasing number of young Moroccan migrants have made their way by illegally travelling to Belgium through Spain and France. Statistics are not available for adults but it has been reported that Belgium is currently hosting 2,000 unaccompanied Moroccan minors who have crossed the external borders of the EU illegally. ${ }^{4}$

One may hypothesise that Belgium has always witnessed the existence of certain forms of undocumented Moroccan migration. The first mobilisation for regularising the undocumented dates back to 1974, immediately 
after Belgium decided to close its borders to official recruitment. ${ }^{5}$ The rise of the undocumented issue as far as Moroccans are concerned is however clearly discernible with the regularisation campaign organised by the federal government in 2000. Out of 37,000 applications, 5,000 were brought by Moroccans $(14.5 \%),{ }^{6}$ representing the second largest group of applicants, after the Congolese.

Although there has been a tightening of Belgian immigration policy, the number of undocumented Moroccan migrants has been rising since the last regularisation campaign according to policy-experts. In fact, the last regularisation campaign in 2000 may itself be accountable for the existence of a remaining pool of rejected applicants or applicants who were only granted short-term residence permits. In addition, not all those undocumented individuals applied for that round of regularisation for various reasons. One undocumented interviewee reported to us that he did not apply for regularisation in 2000 fearing his application could lead him to being deported. He has lived since then in a precarious legal situation but with stable work as an illegal auto-mechanic worker.

There is widespread recognition that the trajectories of undocumented new Moroccan migrants are deeply affected by their social networks. In comparison to other groups of undocumented migrants, Moroccans seem to enjoy a relatively privileged position. Our interviews reveal that these social networks may be of different kinds. On the one hand, there is reliance on already established family networks that may help in finding accommodation, job opportunities, etc. ${ }^{7}$ When they do not have family connections, reference is often made to friends, fellow countrymen or people from the Muslim community. Time and place are elements structuring the formation of these social networks. While Muslim religious solidarity networks become particularly central during specific periods of time, such as during the month of Ramadan, the role of ethnic networks are of particular importance in large urban centres like Brussels, Liège, Antwerp and Charleroi, where a large community is already settled. Large cities do not only offer an advantage in terms of connecting to social networks, they also allow them to avoid the hassle of police control, especially in Walloon cities which are seen as less repressive.

Solidarity networks do not, however, preclude tensions between new and old Moroccan migrants. The discourses of undocumented Moroccan migrants, especially those who are politically mobilised, also insist that the established Moroccan community is not receptive enough to their cause. They tend to consider that, all too often, they turn a blind eye to their concern for survival in everyday life. The role of NGOs has also increased 
significantly in terms of organising the social integration of new undocumented Moroccan migrants. This is especially true for undocumented minors. Several specialised state-funded institutions for youth work have organised themselves to cater for the needs of this specific category of migrants who cannot be legally deported until they reach the age of 18 years. It is also true to say that voluntary associations such as the Union for the Defence of the Undocumented (UDEP), the most representative association of undocumented migrants in the Belgian landscape, has taken a leading role in publicly voicing the claims of this group.

This autonomous political mobilisation of the undocumented is a key feature of the Belgian scene insofar as the option of remaining and functioning without documents in society is not perceived as a realistic or viable option at all. This is also why, before and after the general election of 2007, the UDEP, which had been set up in 2005 after various other platforms and solidarity movements had also been created, has increased political pressure on the Belgian government in the hope of achieving a new regularisation campaign in 2008. The strategy was partly successful and the new Belgian government, set up in March 2008, has announced a new short-term regularisation campaign. Immediately after this agreement was reached at the top governmental level, UDEP also called for a moratorium on deportation. As revealed by existing data, deportation has been significant for new Moroccan migrants. One of our respondents who join the weekly general assembly of UDEP in an occupied Church in the centre of Liège detailed however quite paradoxically that this mobilisation in the open has diminished the fear of police control and subsequent deportation that undocumented migrants were experiencing. Between 1998 and 2004, 10,560 irregular Moroccan migrants were arrested. By 2004, Moroccans ranked first in statistics published by the Immigration Service in numbers of intercepted irregular migrants, representing a fifth of the total number of arrests.

\section{A Tentative Ethnography of New Moroccan Migrants}

Emigration from Morocco has remained very important over the last two decades (Khachani 2004). In the same period, the country has gone through very rapid political and economic changes. The transition from the socalled years of lead, namely the period of political repression under King Hassan II's reign, towards a fragile democratisation process, as well as the sustained growth of the economy since 2001, has presented the country with positive prospects. This has not however been sufficient to meet 
TABLE 2. Number of Intercepted Undocumented Migrants

\begin{tabular}{lccr}
\hline & $\begin{array}{c}\text { Number of intercepted } \\
\text { Moroccan immigrants }\end{array}$ & Total & $\%$ \\
\hline 1998 & 1,228 & 12,704 & $9.6 \%$ \\
1999 & 958 & 13,471 & $7 \%$ \\
2000 & 1,087 & 15,263 & $7.1 \%$ \\
2001 & 973 & 14,913 & $6.5 \%$ \\
2002 & 1,344 & 17,319 & $7 \%$ \\
2003 & 2,061 & 16,715 & $12.3 \%$ \\
2004 & 2,909 & 13,771 & $21.1 \%$ \\
\hline
\end{tabular}

Source: European Migration Network, Belgian Contact Point, 2005. ${ }^{8}$

the tensions of the labour-market and the subsequent tendency among Moroccan citizens to massively devise emigration strategies.

Among our four respondents, emigration is often related to a lack of economic opportunities at home and to the quest for a better future. However, this tends to point out to a form of broader social and economic insecurity. One may talk of a malaise among young people who feel trapped and marginalised in Morocco. Mohamed, a 30 year old undocumented migrant in Belgium and a trained accountant, puts it in his own words:

Even though I had graduated, nothing changed for me and my family. They expected that I would gain autonomy but my plans have not succeeded. Everything remained the same. For anything you do, you have to be lucky in order to escape stalemate and the marginalisation that damp our hopes. That's why I dreamt of leaving the country and discovering Europe even before I graduated.

Prior knowledge of Belgium is rather limited among our respondents. As Mohamed's quote indicates, it is an imagined Europe which stands central in their social representation. Some new Moroccan migrants however tend to accumulate practical information about their emigration plans prior to their departure through networks of family and friends. The internet has also gained in importance, notably for students. Many websites of Moroccan student organisations nowadays offer much practical information on visa requirements and admission procedures to higher education institutions in Europe and North America. ${ }^{9}$ 
Generally speaking, students may apply for a renewable one-year residence permit valid during the time of their study after having successfully been admitted to a school or university. In theory, students come with the initial intention of returning home after their graduation. For them, the immigration scenario is in most cases not written in advance. In practice, however, the status of student has acted as a stepping stone for building long-term immigration plans after having experienced life in Belgium. Such was the case for Amine, a 35 year old man who became an irregular migrant after his short term residence permit expired:

After I finished my studies at the University of Rabat ten years ago, I applied to several Universities in France and Belgium and got finally admitted for a post-graduate degree in economics at the University of Liege. After I completed my studies, I went back to Morocco to try my chance. But after a while I found that Morocco was not ready for hosting us. I came back and took another degree before I started my own business. ${ }^{10}$ (..) Now if I am not regularised in Belgium, I will sell my business and move to Canada without a single hesitation.

A number of Moroccan students have reported to us that they bypassed this legislation by applying for short-term tourist visas and then requesting a student residence permit after entry. A student who opted for this trajectory explained to us that his objective was to work, earning his living, and that then the student residence permit was the most convenient strategy for him to avoid irregularity for the next three to four years.

In terms of employment, cases of new self-employed migrants with a registered company, as with Amine, are quite unusual. The economic integration of new Moroccan migrants is usually less favourable. In practice, undocumented migrants are also generally illegal workers in sectors such as construction, agriculture, cleaning, hotels, restaurants and cafés. Prospects of good economic integration are also a challenge for regularised new migrants. Anwar is a 42 year old Moroccan worker employed in an industrial bakery. He has a long-term residence permit obtained through marriage to a Belgian citizen of Moroccan origin. This is how he sees the question of employment for new Moroccan migrants in Belgium:

In Belgium, it is difficult. There is not much work and you're not well paid. Most of the Moroccans I know are not working (..). When I was in Spain before marrying, I worked hard and earned well. It was a problem because I didn't have documents. But when I compare, I 
was better off in Spain. Here I have documents but if I want to earn a good salary, I have to work after my working hours at the factory.

Both Amine and Anwar are married. While Amine married a former Moroccan student in France who now lives without documents in Belgium, Anwar's spouse is a second generation Moroccan woman established in Belgium. Marriage strategies are an important aspect of the new Moroccan migrants' experience in Belgium. As indicated above, the presence of a large legal Moroccan migrant community directly impacts on the choice of Belgium as a destination country. For many young Moroccan men, whether students or undocumented migrants having overstayed their short term visas, the perspective of marrying a second generation Moroccan woman is another factor in choosing to remain in Belgium instead of moving to other destinations. Available literature and policy experts' views on the matter indicate that this is a phenomenon predominantly at work within Moroccan and Turkish communities in Belgium. Our past and present fieldwork has also encountered numerous instances of such practice. These are quite diversified and seem to widely include the practice of sham-marriages as a migration strategy. It therefore comes as no surprise to see that a focus of the Belgian federal government over the last two legislatures (1999-2003, 2003-2007), has been to tighten the struggle against sham marriages as part of its immigration policy.

\section{CONCLUSION}

Moroccans in Belgium come close to being the largest immigrant community in the country. It is characterised by being both in a post-migration and migration situation. While there has been extensive research on legally established Moroccan migrants in the country, the trajectories of new Moroccan migrants has not been dealt with specifically in the literature. The burgeoning analyses of undocumented migrants in Belgium offer very interesting insights on the issue. Dwelling on both existing research and on our own fieldwork material, we have sought to better identify one important figure among new Moroccan migrants, namely undocumented migrants. This obviously gives only a partial picture that would need to be complemented by a more systematic analysis of other significant categories of new migrants such as the family dependents. We nevertheless believe that this account provides a number of indications as to the regularities of the migratory experience of recent Moroccan migrants. 
The conceptual framework at the heart of this collective research project sought to better understand the impact of policy on migrants' plans and strategies. Conceptually, one may then identify a nodal point when the former influences the later. Through this exploration of the experience of new Moroccan migrants in Belgium, one may conclude by saying that the increasingly restrictive migration policy is, by and large, an ignored nodal point in both pre-migration decisions to leave and post migration decisions to remain undocumented in the country. Students overstaying their visas offer another example of an ignored nodal point. In a context where undocumented migrants are strongly mobilised politically, anticipations are made that a new wave of regularisation will soon take place, a situation which paradoxically lead to increase the salience of these ignored nodal points. Actual nodal points corresponding to the encounter between a state policy and a migrant's decision is discernible in the migration for family reunion which is used by large numbers of new Moroccan migrants. This channel of immigration places family dependent in a much more favourable social condition than the undocumented even though the labour-market integration was pointed out as problematic. The actual nodal points also lead to increase missed nodal points which in the case of Moroccans in Belgium lies at the juncture of the social experience of an older and newer community of migrants. In recent years, the Belgian government has placed a strong emphasis on struggling against sham marriages in recent years, but at the same time, it is observable that matrimonial and migration strategies are nowadays increasingly entangled.

\section{NOTES}

1. National Institute for the Statistics, 2006.

2. SPF Intérieur, Office des étrangers: http://www.dofi.fgov.be/fr/statistieken/ statistiques_etrangers/Stat_ETRANGERS.htm

3. In addition to these channels, Belgian legislation offers the possibility of applying for regularisation on humanitarian grounds. It is a discretionary procedure of the Minister of Interior also known as the procedure of 'Article 9.3.'

4. Exil en mode mineur. Terminus Bruxelles. Le Soir, November 6, 2007.

5. This was a result of an important mobilisation among Moroccan selforganisations, trade unions and solidarity organisations. Under their pressure, Belgium organised a wave of regularisation in July and August 1974, which resulted in the regularisation of 7,448 undocumented immigrant workers out of 8,516 applicants (Bousetta, 2001).

6. Overall the percentage of accepted cases stood at around $80 \%$. 
7. Hosting undocumented family members does not seem to be uncommon for Moroccan families. In comparison to the mobilised segment of the undocumented population, it is an invisible phenomenon very difficult to assess in both quantitative and qualitative terms.

8. http://www.dofi.fgov.be/nl/statistieken/belgian\%20migration\%20point/ Illegally\%20Resident\%20TCN\%20in\%20Belgium\%20final.pdf

9. See for instance http://www.etudiant.ma/

10. The business in question is a phone shop.

\section{REFERENCES}

Bousetta, H. (2001). Immigration, Post-immigration Politics and the Political Mobilisation of Ethnic Minorities. A comparative Case-Study of Moroccans in Four European Cities. Unpublished $\mathrm{PhD}$ dissertation, Brussels, KUBrussel.

Boussetta, H. \& Martiniello, M. (2003). L'immigration marocaine en Belgique. Du travailleur immigré au citoyen transnational. Hommes et Migrations, March 2003.

Bousetta, H., Gsir, S., \& Martiniello, M. (Eds.) (2006). Les migrations marocaines vers la Belgique et l'Union européenne. Regards croisés. Deusto: Deusto University Press.

Khachani, M. (2006). La migration clandestine au Maroc. In H. Bousetta, S. Gsir, \& M. Martiniello (Eds.) Les migrations marocaines vers la Belgique et l'Union européenne. Regards croisés. Deusto: Deusto University Press.

\section{APPENDIX}

Interviews with new Moroccan migrants:

- Mohamed, a 30 year old man, trained accountant, undocumented migrant, interview conducted in Brussels.

- Amine, a 35 year old man, self-employed, undocumented migrant, interview conducted in Liège.

- Anwar, a 42 year old man, works in an industrial bakery, family dependent migrant, interview conducted in a suburb of Liège.

- Nacera, a 36 years old woman, teacher of Islamic classes, family dependent migrant, interview conducted in Brussels.

Interviews with policy-experts:

- Mr P.L, officer at the Belgian Federal Ministry of Social Integration.

- Mr R.E., advisor at the Walloon regional government.

- Mrs D.C, member of the staff of the mayor of the city of Liège. 